\title{
Application of analog and numerical models to investigate the influence of drainage on workability in spring
}

\author{
G. P. Wind
}

Institute for Land and Water Management Research, Wageningen (ICW), the Netherlands

Key words: analog models, numerical models, drainage, workability, soil moisture, water flow

Accepted: 20 February 1976

\section{Summary}

Models of non-steady unsaturated flow of moisture were used to calculate moisture conditions in a top soil from natural rain- and evaporation data over 23 years. The calculations were made with 5 drainage depths and 3 drainage intensities. This was done with an available analog model, mathematical models being anyway too expensive for calculations over such a long period. The most difficult problem in the application of the analog model was to insert the proper soil conditions. This was solved by changing them until the model calculation for one year fitted the workability conditions observed in the field. The results of the then resulting calculations could be verified with field observations available for all 23 years.

The number of workable days and the first date of workability did show large variations over the years. Drainage depth had a pronounced effect on workability, drainage intensity had hardly any effect.

\section{Introduction}

Workability in spring for seedbed preparation is a very important topic in arable agriculture. It influences the amount of labour and machinery required and the date of sowing.

Deficient workability in spring causes too late planting dates and thus a decrease in yield. But it also causes problems in the performance of farming operations. There are direct ways to solve these problems (e.g. additional labour, working at night and during the weekend, help by contractors) but production costs increase when the soil shows poor workability and planting cannot be delayed too much. So in a bad spring the farmer has to make his decisions to minimize the total losses resulting from higher costs and lower yields.

Farming practice depends on an equilibrium, found from experience, between number and date of workable days, crop succession, machinery selection and labour 
force in normal years. In order to find a better equilibrium by optimalization techniques and for example to calculate the benefits of better drainage, more basic knowledge on the occurrence of a good workability is needed.

Workability depends on the amount of moisture in soil and drainage measures will affect this. Workability in spring, however, especially depends on moisture conditions of the top layer which are far more dependent on accidental fluctuations in rainfall and evaporation rate than the amount of moisture in the total soil. The moisture condition of top soil therefore cannot be calculated as simply as the total soil moisture content. With the aid of models of unsaturated flow such calculations have become possible, however.

In order to improve workability in spring by optimum drainage it is necessary to know how drain depth and drain spacing does affect is. This could be studied at an experimental field but this study will take many years as due to the variations in rainfall and evaporation rate than the amount of moisture in the total soil. drainage in this respect is to be defined as a drainage which ensures sufficient workable days in nine out of then years on the average. Therefore such an investigation in the field would have to last at least some decades to find statistically reliable information.

With a model the study can be made over a large number of years in a short time.

\section{Models used}

With the model the moisture content of the top soil will have to be calculated from input data such as rainfall, evaporation, soil properties and drainage. Therefore it must be a model which simulates non-steady state processes of flow and accumulation of moisture in unsaturated soil; moreover it must incorporate a good function of drainage.

Most models are mathematical, which nowadays means computer-models. For the least expensive computer-model the processing cost is about $\$ 0.40$ per calculated day. Even then calculation of 23 springs of each 120 days for 3 drain depths and 3 spacings would cost $\$ 10000$. In practice the costs would be still higher.

Another type of model is the analog-model. The real processes which occur in the soil are then represented by analogous processes. Flow of water is for instance replaced by flow of electricity. The condition for a physical analog is that the equations on which the model is based are the same as those describing reality. Such analogues have to be built and automatized, which costs time and money, but once this is done the operation costs are almost negligible. With the hydraulic analog I described (Wind, 1972) investigation could be done cheaply.

The model consists of a number of vessels, each representing a soil layer. The amount of water in a vessel represents the soil moisture content, the height of the water level the soil moisture suction. The vessels are connected by a number of tubes at different elevation. Because the tubes above the water level in the vessels do not transport water, the transport capacity of the tubes depends on the height of the water level. In this way, if they have correct dimensions, the tubes can give a good simulation of capillary conductivity. 


\section{INFLUENCE OF DRAINAGE ON WORKABILITY IN SPRING}

The scales of the model are: $S_{\mathrm{v}}=0.1(1 \mathrm{~cm}$ of suction is represented by $0.1 \mathrm{~cm}$ in the model), $S_{a}=900 \mathrm{~cm}^{2}\left(1 \mathrm{~cm}\right.$ water layer is represented by $\left.900 \mathrm{~cm}^{3}\right), S_{\mathrm{i}}=$ $1 / 288$ ( 1 day in reality is represented by 5 minutes in the model).

For part of the investigation mathematical models were used. They were described by van Keulen \& van Beek (1971) and Wind \& van Doorne (1974).

\section{Workability}

Workability in spring is the soil condition with which a good seedbed can be made with the usual tools. The soil should fall into small crumbs, not into clods and certainly not be smeared or puddled. According to Perdok (1975) the behavior of soil in this respect is dependent on its mechanical strength. The tillage results obtained and the mechanical strength are highly correlated with the soil moisture tension.

In this paper a mean moisture suction of $-300 \mathrm{~cm}$ in the top $5 \mathrm{~cm}$, is presumed to be the limit for workability. Wetter conditions impede good tillage. Further it is assumed that a lower limit (for dry conditions), has no practical meaning for professional farmers on the loam soil studied.

The depth of $5 \mathrm{~cm}$ was chosen arbitrarily. For the seedbed of grains less depth

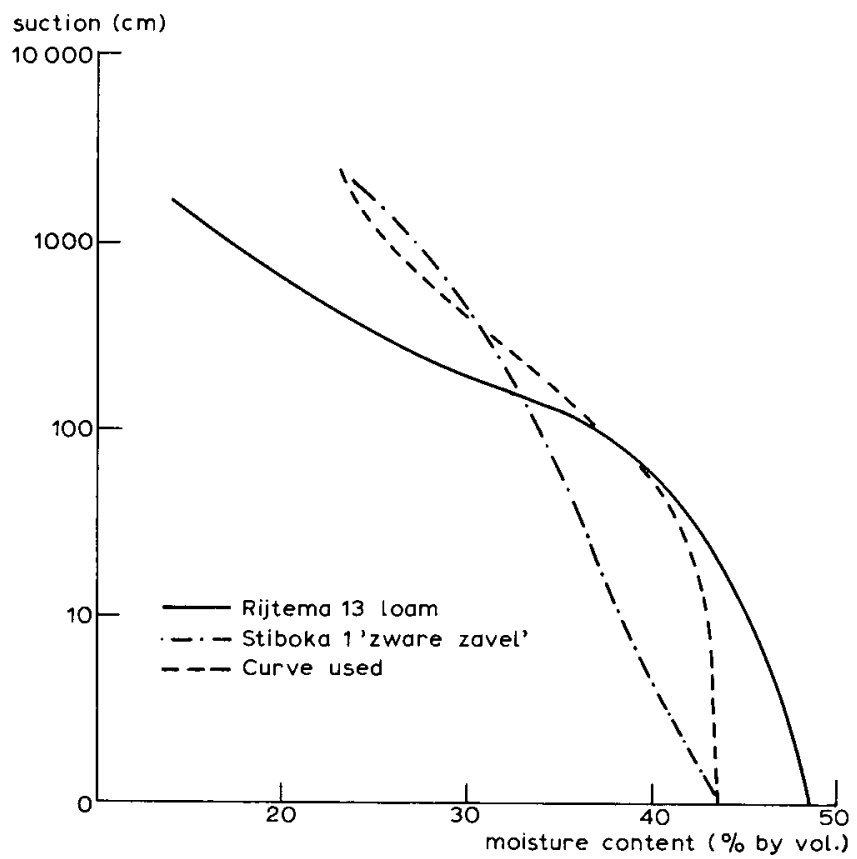

Fig. 1. Soil moisture characteristics of 'Rijtema 13' loam, Stiboka 1 'zware zavel' and the soil used in the model. 
is sufficient, for that of potatoes it should be $7 \mathrm{~cm}$ (Perdok, 1975). For sugarbeet about $5 \mathrm{~cm}$ must be tilled.

\section{Soil properties}

The study was made for loam soil. The 'model'-soil was meant to represent the properties of the arable soil called 'zware zavel' in Dutch, which occurs in the Hoekse Waard. Some observations on moisture content and workability in this polder were made in 1973 by Perdok (1974).

As no data on capillary conductivity, the $\mathrm{k}(\psi)$ relation, were known, the standard soil no. 13, loam of Rijtema (1969) was used for this purpose. A hydraulic model was built based on the moisture characteristic shown in Fig. 1 and on the $\mathrm{k}(\psi)$ relation where $\mathrm{k}_{0}=5 \mathrm{~cm} \cdot \mathrm{day}^{-1}$ and $\alpha=0.023 \mathrm{~cm}-1$. The first test-run made

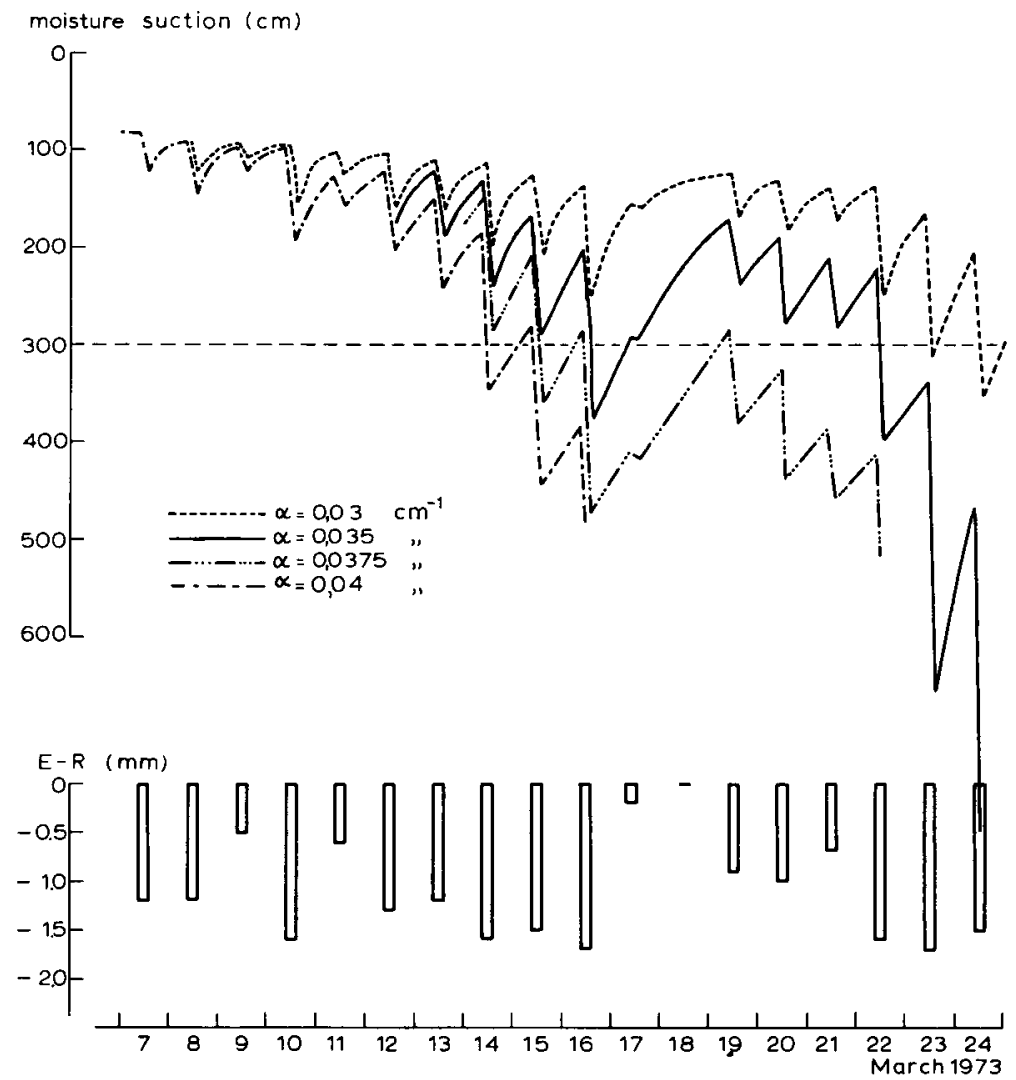

Fig. 2. The value of $\alpha$ in the relation $\mathrm{k}=\mathrm{k}_{0} \mathrm{e}^{\alpha} \mathrm{x}$ ) was found by trying what value fitted best the field observations which indicate that the topsoil was drier than $300 \mathrm{~cm}$ during a short time on 16 March and during a longer period beginning 22 March. 
with the meteorological data of 1960 was a disappointment. This year was known for its favourable tillage conditions in spring, but the model showed non-workable soil conditions up to 30 April.

After checking the model specifications the cause seemed to be the use of wrong soil properties. These could simply be changed by increasing the scale for area $\left(S_{\mathrm{a}}\right)$ of the model, as both $k_{0}$ and the moisture contents are inversely proportional to $S_{a}$.

A small change of $S_{\mathrm{a}}$ from the original value of 500 to $600 \mathrm{~cm}^{2}$ was not sufficient. Nor was an increase to $1000 \mathrm{~cm}^{2}$ even when combined with a very deep drainage. In none of the test-runs for 1960 was workability reached. Apparently the discrepancy with the actual soil properties was large and it was thought it concerned the exponent $\alpha$ of the $\mathrm{k}(\psi)$ relation.

It was then decided to relate the soil properties, especially $\alpha$, to actual workability data in the Hoeksche Waard as known for 1973. First the moisture characteristic of the model, based on the 'Rijtema 13' soil, was reduced to the curve given by

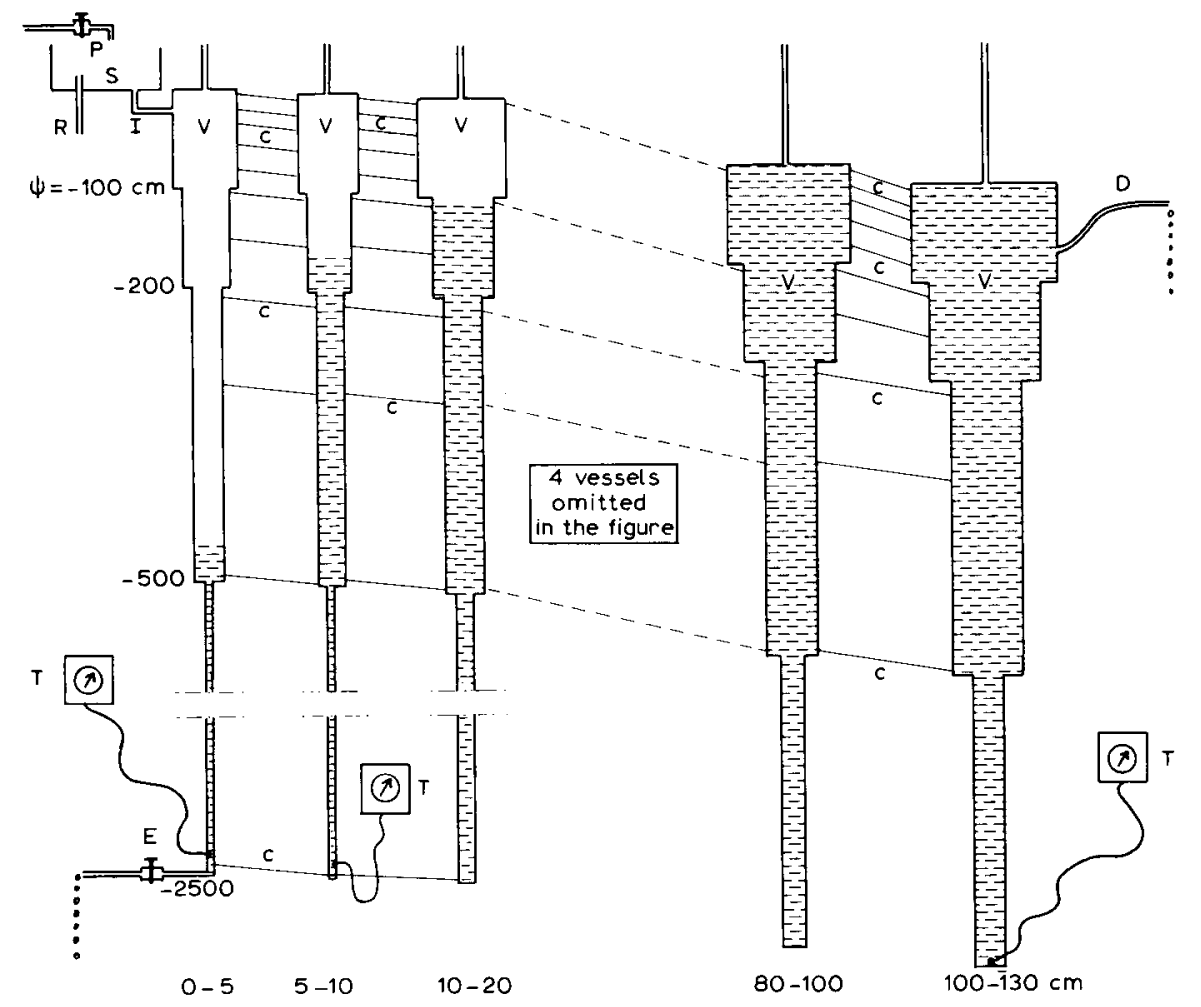

Fig. 3. Outline of the hydraulic analog used. V: vessels representing a soil layer of a certain thickness and a certain moisture characteristic; $C$ : connecting tubes, representing capillary conductivity; $P$ : precipitation valve; $S$ : surface tank with $R$ : run-off pipe, I: infiltration tube; E: evaporation valve; $T$ : pressure transducer, connected with recorder and data logger; D: drainage tube. 
Anon. (1971). This was done by increasing the scale of $S_{2}$ from 500 to $900 \mathrm{~cm}^{2}$. In this way adjusting the moisture contents in the model fitted closer to the Stiboka moisture characteristic. This is shown in Fig. 1.

Determination of the coefficient $\alpha$ from field observations by inductive use of a mathematical model

The rainfall data of 1973 from the experimental farm 'Westmaas' on the island Hoeksche Waard showed much precipitation up to 7 March, with a mean of $0.2 \mathrm{~cm}^{\cdot \mathrm{day}^{-1}}$ in the last 10 days. On 7 March a clear period began with evaporation rates between 0.05 and $0.17 \mathrm{~cm} \cdot$ day $^{-1}$, which lasted until 17 March. Then light rainfall occurred so that the difference between evaporation and rainfall was nearly zero on 17 and 18 March. After that a new evaporation period started (Fig. 2).

On 17 March the soil was nearly workable, but workability ended next day and it returned on 22 March. A soil parameter $\alpha$ had to be found with a value such that

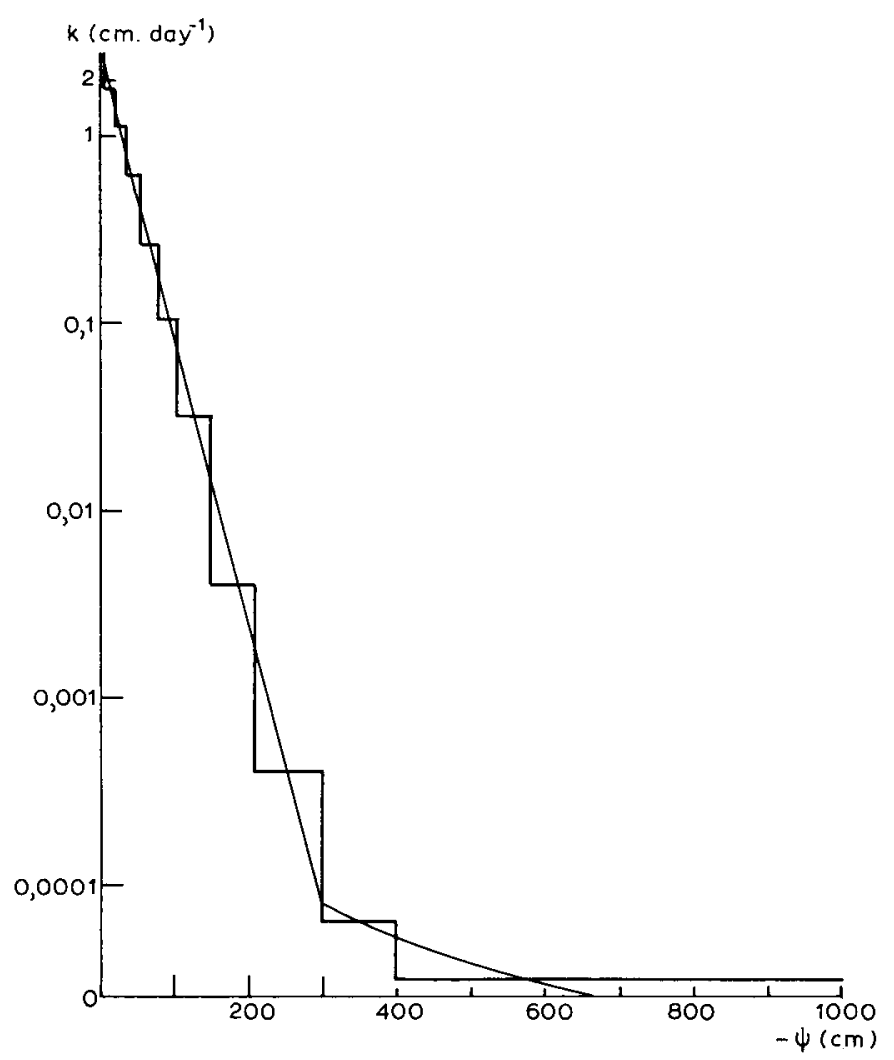

Fig. 4. The $\mathrm{k}(\psi)$ relation is simulated in the model by a step-curve. 
the given weather input would give an output equal to the workability situation observed in the field.

The mathematical model 'Flow' of Wind \& Van Doorne (1975) was used to calculate the moisture suctions in the top $5 \mathrm{~cm}$. The initial condition on $7 \mathrm{March}$ was a dynamic equilibrium at $0.2 \mathrm{~cm}^{\cdot}$ day $^{-1}$ downward flow. This means a depth of the groundwater table $80 \mathrm{~cm}$ below surface, with a drainage depth of $100 \mathrm{~cm}$ and intensity of $0.01 \mathrm{day}^{-1}$. The conductivity at zero suction $\left(\mathrm{k}_{\mathrm{o}}\right)$ was $2.8 \mathrm{~cm} \cdot \mathrm{day}^{-1}$, the moisture characteristic as given in Fig. 1 (curve used). Evaporation rates were used as shown in Fig. 2. It was assumed that the evaporation had a constant rate for 0.2 days in the middle of each day and that during the rest of the day no evaporation occurred.

The first run was made with $\alpha=0.03 \mathrm{~cm}^{-1}$. Workability was reached on $24 \mathrm{March}$, two days too late. The second run with $\alpha=0.04 \mathrm{~cm}^{-1}$ gave workability on 14 March, two days too early. The third run with $\alpha=0.035 \mathrm{~cm}^{-1}$ described exactly what did happen in the field: a nearly workable soil on $17 \mathrm{March}$ and definitely so on 22 March. An additional run with $\alpha=0.0375$ gave conditions that were too dry. So the value of $\alpha$ was set at $0.035 \mathrm{~cm}^{-1}$.

Apparently, such models can be used to obtain soil property data from simple field data.

\section{Specifications of the model}

After determination of $\alpha$, the model (Fig. 3) was rebuilt to a capillary conductivity described by

$$
\mathbf{k}=2.78 \mathrm{e}^{0.035} \psi(\psi>-300 \mathrm{~cm}) \text { and } \mathbf{k}=0.225 \psi^{-1,4}(\psi<-300 \mathrm{~cm})
$$

This was realized in a step-curve by tubes at suction values of $5,20,35,55,80$, $105,210,300,500,1000,1500,2000$ and $2500 \mathrm{~cm}$. See also Figs 3 and 4.

The scale for area was made $900 \mathrm{~cm}^{2}$, so a water layer of $1 \mathrm{~mm}$ was represented by $90 \mathrm{ml}$ water. The vertical scale was made 0.1 , so a difference of $10 \mathrm{~cm}$ in moisture suction was represented by $1 \mathrm{~cm}$ in the model. As the maximum height of the room was $2.50 \mathrm{~m}$, the driest condition was $\psi=-2500 \mathrm{~cm}$.

In order to follow the moisture characteristic (curve used) of Fig. 1 the vessels were divided in 4 sections according to Table 1.

For vessels representing layers of different thickness the volume was changed in

Table 1. Volume, length and diameter of the sections of a vessel representing a layer of $10 \mathrm{~cm}$.

\begin{tabular}{rllcl}
\hline $\begin{array}{l}\text { Suction range } \\
(\mathrm{cm})\end{array}$ & $\begin{array}{l}\text { Moisture content } \\
(\% \text { by volume })\end{array}$ & $\begin{array}{l}\text { Volume } \\
(\mathrm{ml})\end{array}$ & $\begin{array}{l}\text { Length } \\
(\mathrm{cm})\end{array}$ & $\begin{array}{l}\text { Diameter } \\
(\mathrm{cm})\end{array}$ \\
$0-100$ & $43.6-36.8=6.8$ & 612 & 10 & 8.8 \\
$100-200$ & $36.8-33.0=3.8$ & 342 & 10 & 6.6 \\
$200-500$ & $33.0-28.8=4.2$ & 378 & 30 & 4.0 \\
$500-2500$ & $28.8-23.2=5.6$ & 504 & 200 & 1.8 \\
\hline
\end{tabular}


proportion. In total there were 11 vessels representing the layers $0-5,5-10,10-20$, $20-30,30-40,40-60,60-80,80-100,100-130,130-160$ and 160-190 cm depth. The time scale was 0.00347 , which means that one actual day was represented by 5 minutes in the model.

\section{Rainfall}

The input on paper tape was read in every minute in 5 periods per day. As nothing was known about the distribution of rain over the day, the rain was distributed equally over the periods in the day. The tape-reader opened and closed a valve by which water entered the top of the model at a rate of $2700 \mathrm{ml}$ per $5 \mathrm{~min}(30 \mathrm{~mm}$ rain per day). If less rain was read, the valve opening time was reduced proportionally to multiples of 2 seconds.

Rainfall and evaporation data were used which had been observed in the meteorological station of De Bilt in the centre of the Netherlands.

\section{Evaporation}

As no daily evaporation data were available, data of 10 or 30 day totals had to be used. These data could not be distributed evenly over the days. On sunny days there should be more evaporation than on cloudy days. As radiation is the most important factor governing evaporation, daily radiation data, observed in De Bilt were, by linear interpolation, used for the distribution. The evaporation was presumed only to occur during the third of the 5 periods in the day. The tape-reader opened and closed a valve near the bottom of the model by which water left the upper vessel $(0-5 \mathrm{~cm}$ deep soil layer) of the model at a rate of $270 \mathrm{ml}$ in one minute, equivalent to $15 \mathrm{~mm}^{\cdot \text { day }^{-1}}$. For smaller evaporation rates the opening time was reduced. Evaporations of more than $3 \mathrm{~mm}$ were distributed over the third and fourth period of the day.

By placing the evaporation valve at the lowest place of the model, i.e. at suction value of $2500 \mathrm{~cm}$, the real evaporation was lower than the potential, according to:

$$
\mathrm{E}_{\mathrm{r}}=\mathrm{E}_{\mathrm{p}} \frac{2500+\psi}{2500}[\psi>-2500]
$$

This function was chosen because it can easily be realized in a hydraulic model. Hoogmoed (1974) tried another function in a mathematical model, based on the CSMP-model of van Keulen \& van Beek (1971) and found only small differences (Fig. 7). This function reduced potential evaporation in proportion to the ratio of moisture content and maximum moisture content of the top $5 \mathrm{~cm}$. It gives larger reductions in wet conditions and smaller ones in dry conditions than the function used in this article.

The function and mechanism used here reduce high evaporation rates more than low ones.

\section{Run-off}

In rainy periods the infiltration rate of the model may be lower than the precipitation rate. In order to simulate ponding, a special tank was made on top of the model. 


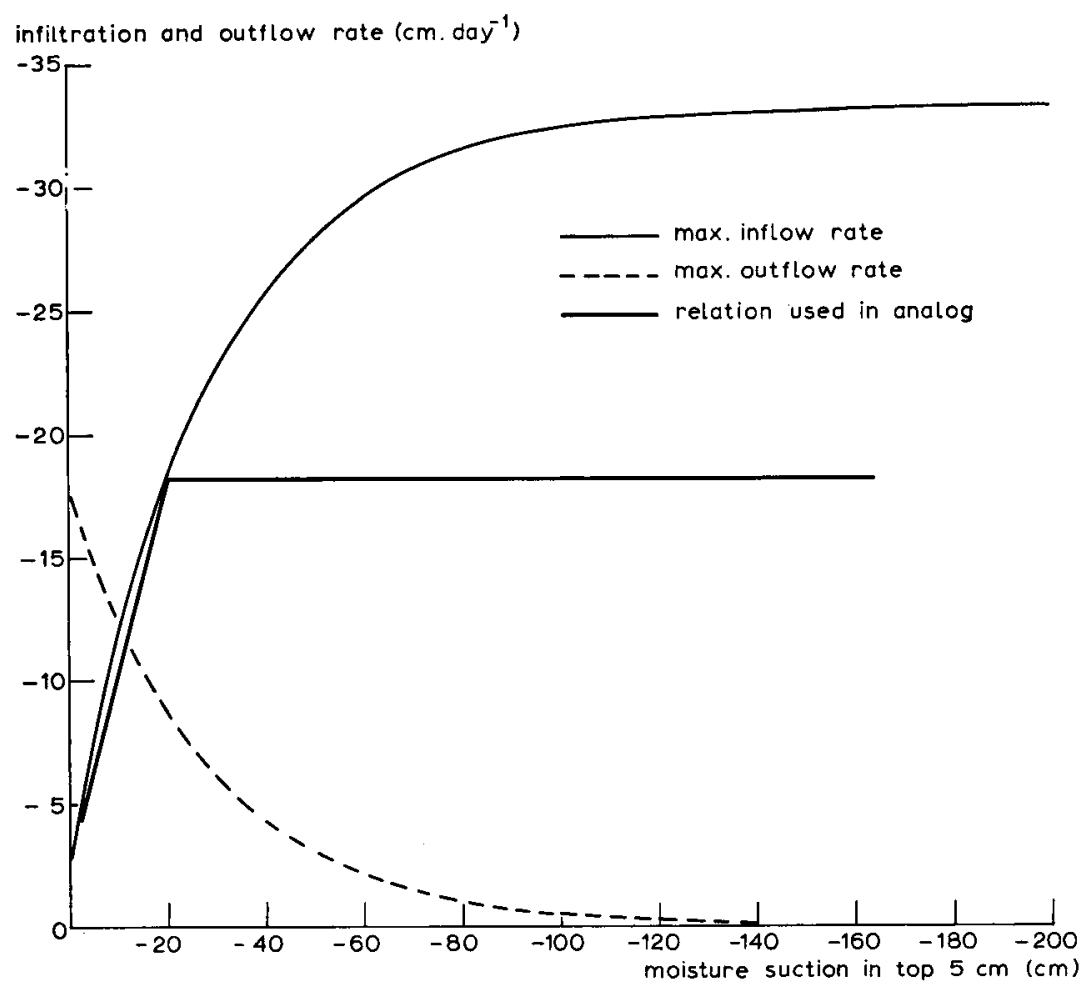

Fig. 5. Maximum inflow rate and maximum outflow rate as related to suction in the top $5 \mathrm{~cm}$, and the relation used in the model.

Its content was $270 \mathrm{ml}(0.3 \mathrm{~cm}$ water layer $)$. An excess could flow out of that tank and thus simulate run-off. This occurred only with poor drainage.

\section{Infiltration}

Infiltration depends on the suction in the first layer, as shown in Fig. 5. It was simulated in the model, in a way given in the same figure, by a tube connecting the surface tank with the first vessel at a point corresponding with $\psi=-20 \mathrm{~cm}$. In drier conditions the infiltration rate is very high compared with the maximum flow velocity between the two first vessels. Then the moisture content of the top vessel increases so fast that even a large mistake in the infiltration rate is unimportant for the problem studied. The maximum flow rate at $5 \mathrm{~cm}$ depth was calculated under the assumption that the layer 5 to $10 \mathrm{~cm}$ has a moisture suction of $-2500 \mathrm{~cm}$.

\section{Drainage}

It was supposed that the flow of water from surface to drain was vertical to drain depth and horizontal from that depth to the drain. Therefore the drainage tube was 
always connected to the vessel representing the layer in which the drain was thought to be situated. The model was supposed to represent a place midway between two drains.

\section{Registration}

The height of the watertable was read in the two top vessels and in the drainage vessel with pressure transducers. Their readings were recorded by line-recorders and by a paper tape writer. The tape could be fed into a computer.

\section{Check on the calculations}

An unexpected opportunity to check the results derived with the model occurred when it became known that at the Agricultural Extension Service in the polder 'Hoeksche Waard', Mr Hokke had made daily notes on the soil condition for more than 25 years. Every day he had made a note whether the top soil was very wet, wet, moist, dry or very dry.

In spring the notations 'dry' and 'very dry' meant that the soil was fit for tillage. In Fig. 6 the number of workable days are given according to Hokke's observations and according to the analog model. For that purpose the model was fed with the relevant rainfall data of the Hoeksche Waard, taking a drainage depth of $100 \mathrm{~cm}$ below surface and a drainage intensity $\mathrm{A}$ of $0.012 \cdot \mathrm{day}^{-1}$.

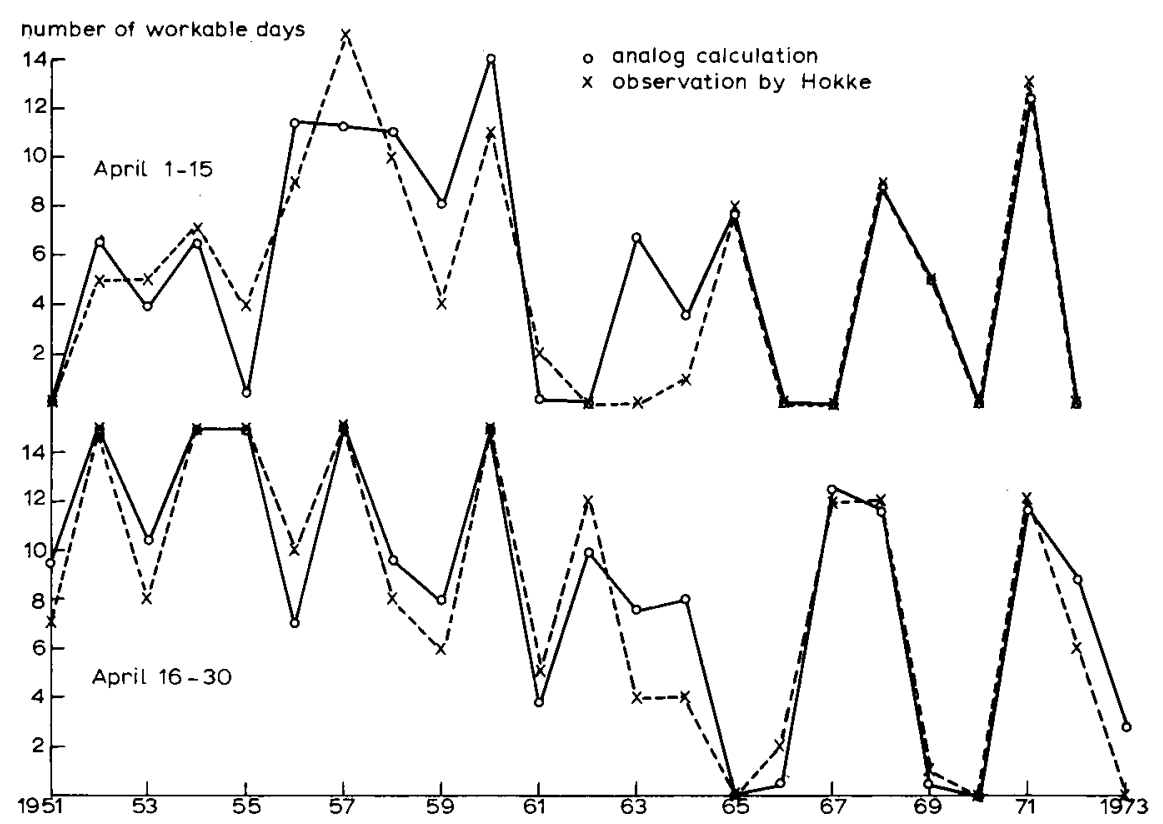

Fig. 6. Comparison of the calculated and the by Mr Hokke observed number of workable days in the Aprils of 1951 through 1973. 


\section{INFLUENCE OF DRAINAGE ON WORKABILITY IN SPRING}

Table 2. Drain depths and intensities used in the model observations.

A: over all years between 1951 and 1973 except 1960; S: over some years only.

\begin{tabular}{|c|c|c|c|c|}
\hline \multirow{2}{*}{$\begin{array}{l}\text { Depth } \\
\text { (cm below surface) }\end{array}$} & \multicolumn{4}{|c|}{ Intensities (day - 1) } \\
\hline & $\overline{0.0011}$ & 0.0033 & 0.008 & 0.015 \\
\hline 0 & & & & $\mathbf{S}$ \\
\hline 40 & & & & A \\
\hline 80 & & $S$ & $S$ & $S$ \\
\hline 100 & & & & $\mathbf{A}$ \\
\hline 150 & $S$ & $S$ & $S$ & $\mathbf{A}$ \\
\hline 200 & & & & A \\
\hline
\end{tabular}

Observed and calculated data agree quite well. The deviations can be caused by a number of factors, e.g. the subjective interpretation of soil condition by Hokke, and incorrect drainage input, an unequal distribution of rain over the polder or differences in the soil physical properties. The differences in workable days between

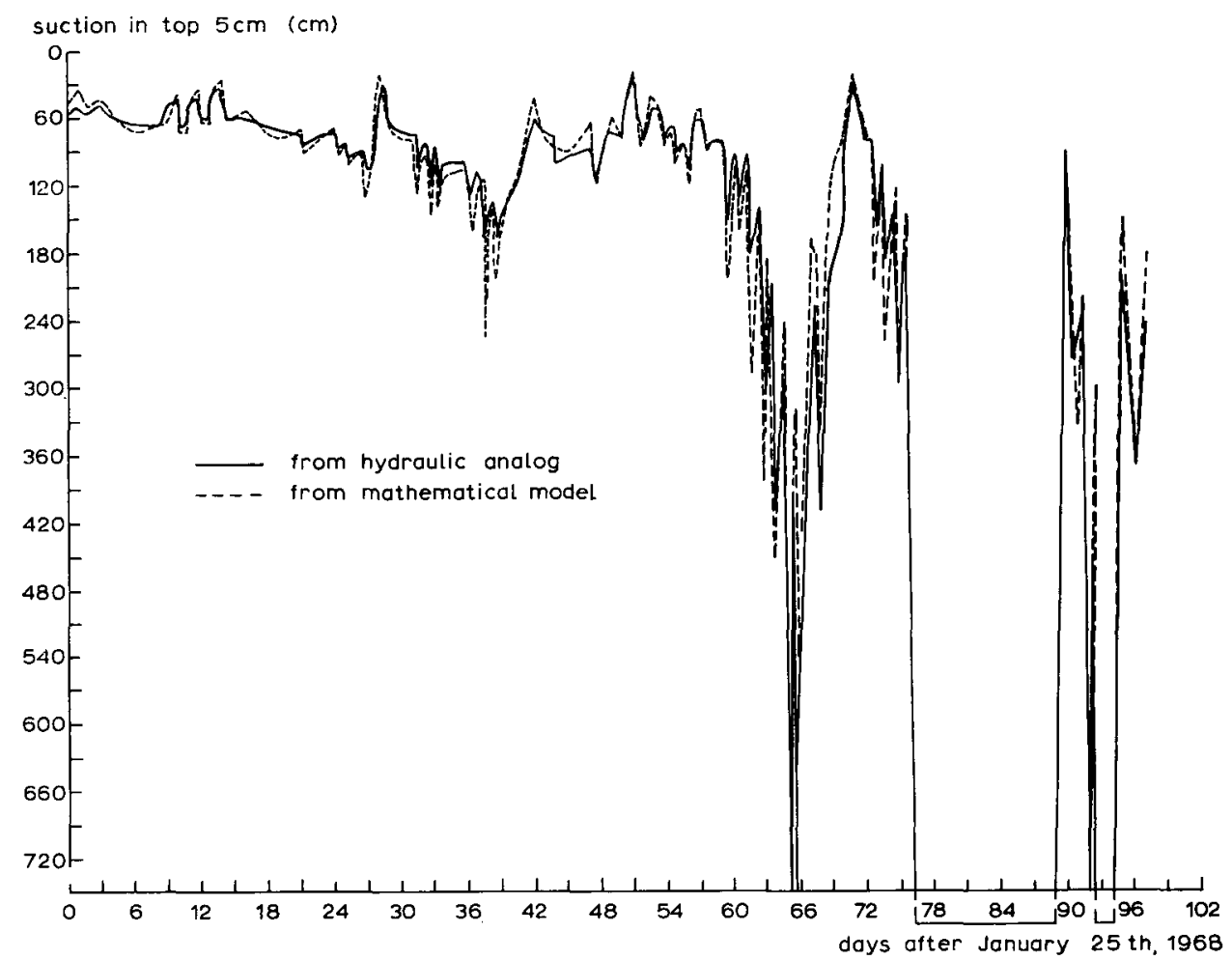

Fig. 7. Moisture suction in the top $5 \mathrm{~cm}$ in the spring of 1968 as calculated by hydraulic analog and by mathematical model of van Keulen \& van Beek (1971) and Hoogmoed (1974). 
the model - and Hokke's observations were always positive when small amounts of rainfall occurred during a workable period. Hokke could have seen the surface as moist, but the mean amount of moisture in the top $5 \mathrm{~cm}$ measured by the model would be less. The differences are fairly large in 1963 and 1964. It later appeared that both years drainage depth had pronounced effect on workability (Fig. 11).

\section{Observations}

The number of workable days was determined with the aid of the analog during the months March and April of the years between 1951 and 1973. Evaporation and rainfall data were used from the meteorological station De Bilt in the centre of the Netherlands. Each simulation started on 1 January. The initial condition was derived from a rough calculation based on precipitation and evaporation in the preceding summer and autumn. In most years the effect of the initial condition on the moisture condition of 1 March appeared to be negligible, except for 1960 when a very dry summer was followed by a dry autumn and winter. The results of that year were therefore omitted.

The data on workability were determined for a number of drainage depths and intensities as shown in Table 2.

\section{Results}

For each year and each combination of drainage depth and intensity a graph was
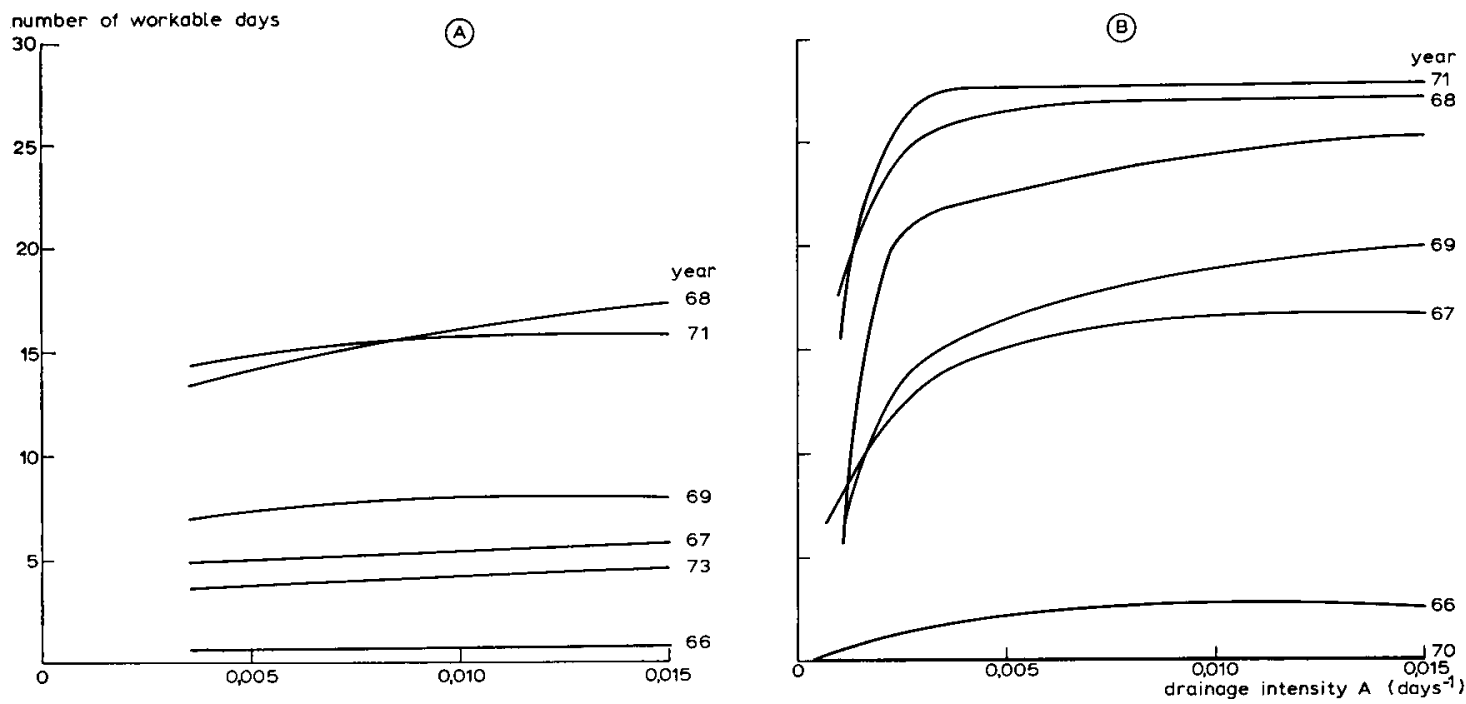

Fig. 8. A: relation of workable days before 1 May and the drainage intensity for a drain depth of $80 \mathrm{~cm}$; B: the same for a drain depth of $150 \mathrm{~cm}$. 
produced as Fig. 7, giving the moisture tension in the top $5 \mathrm{~cm}$. The number of workable days could be read from these graphs or from the punched tape of the recorder.

In Fig. 8A for the six mentioned years the relation is given for the number of workable days and drainage intensity for a drainage depth of $80 \mathrm{~cm}$. The influence of the drainage intensity seems to be small. Only for very low intensities is the influence important. But such intensities are not important because there are other reasons than workability which require an intensity larger than 0.0033 . With that intensity a soil drained at $80 \mathrm{~cm}$ depth has a watertable situated at less than $20 \mathrm{~cm}$ depth even during the mean winter rainfall of $0.2 \mathrm{~cm}^{\cdot} \mathrm{day}^{-1}$.

For a $150 \mathrm{~cm}$ drain depth, as shown in Fig. 8B, nearly the same conclusions hold: the influence of the drainage intensity is large only for intensities lower than 0.0033 . This intensity gives a discharge rate of $0.33 \mathrm{~cm} \cdot$ day $^{-1}$ if the watertable is $50 \mathrm{~cm}$ below surface (neglecting the vertical resistance), so it is about half the intensity required by the Netherlands' drainage criterion. The latter requires for arable soils a discharge rate of $0.7 \mathrm{~cm} \cdot$ day $^{-1}$ if the watertable is $50 \mathrm{~cm}$ below surface.

Wesseling (1969) calculated that this criterion causes a groundwater depth of $25 \mathrm{~cm}$ with a probability of once a year. Apparently the requirement for water

Table 3. Total number of workable days in March and April in relation to drainage depth.

\begin{tabular}{rrrrr}
\hline \multicolumn{2}{c}{ Drainage depth $(\mathrm{cm})$} & & \\
\cline { 2 - 4 } Year & 40 & 100 & 150 & 200 \\
1951 & 5 & 7 & 7 & 9 \\
2 & 14 & 20 & 24 & 25 \\
3 & 8 & 26 & 29 & 33 \\
4 & 19 & 24 & 25 & 30 \\
5 & 13 & 13 & 23 & 23 \\
6 & 15 & 30 & 33 & 35 \\
7 & 16 & 24 & 25 & 26 \\
8 & 4 & 12 & 17 & 18 \\
9 & 2 & 4 & 6 & 6 \\
1961 & 0 & 4 & 8 & 10 \\
2 & 1 & 4 & 4 & 5 \\
3 & 1 & 9 & 12 & 13 \\
4 & 0 & 14 & 8 & 13 \\
5 & 0 & 4 & 2 & 2 \\
6 & 1 & 1 & 11 & 14 \\
7 & 4 & 10 & 23 & 13 \\
8 & 13 & 20 & 0 & 0 \\
9 & 3 & 7 & 22 & 22 \\
1970 & 0 & 0 & 18 & 18 \\
1 & 11 & 20 & 16 & 17,1 \\
2 & 7 & 16 & 15,4 & \\
1973 & 1 & 14 & & 21 \\
& & 12,5 & & \\
Average & 6,2 & & & \\
\hline
\end{tabular}


removal in winter is more severe than that for workability in spring. The conclusion therefore is that the requirement of good workability in spring hardly influences the choice of the drainage criterion.

The influence of drainage depth on workability (Table 3 ) is very important, as is shown in Fig. 9. There seem to be three types of spring:

1. In years such as ' 66 and ' 70 there is a poor workability regardless of drainage depth. This is caused by a very small number of rainless days ('70) or by only short periods without rain ('66).

2. In years like ' 68 and ' 71 even at shallow drainage depths a high workability exists. Although there is a marked influence of drainage depth on workability, even shallow depths give enough workable days.

3 . In many years drainage depth is very important for the spring cultivations. To this type belong 10 of the 22 investigated years.

The number and distribution of workable days in spring is important for the choice of type and size of farm machines and for the organization of farm work. Mostly it only slightly affects labour costs because the labour peak is not in spring but in autumn. More workable days primarily do not mean an improvement of the
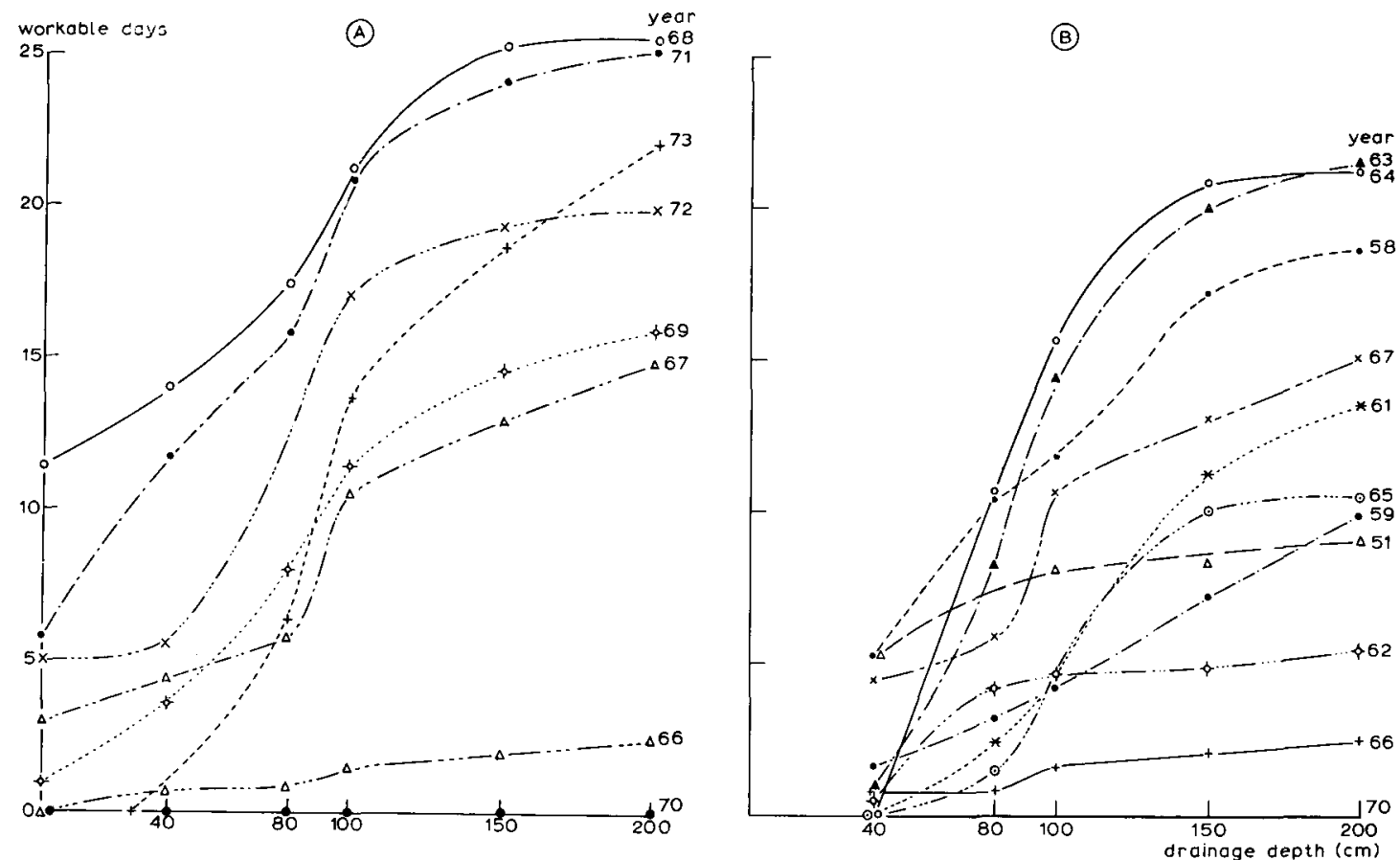

Fig. 9. A: number of workable days before 1 May in the last 8 years for different drainage depths and a constant drainage intensity of 0.015 day-1; B: the same for some years with a low workability at shallow drainage depths. 


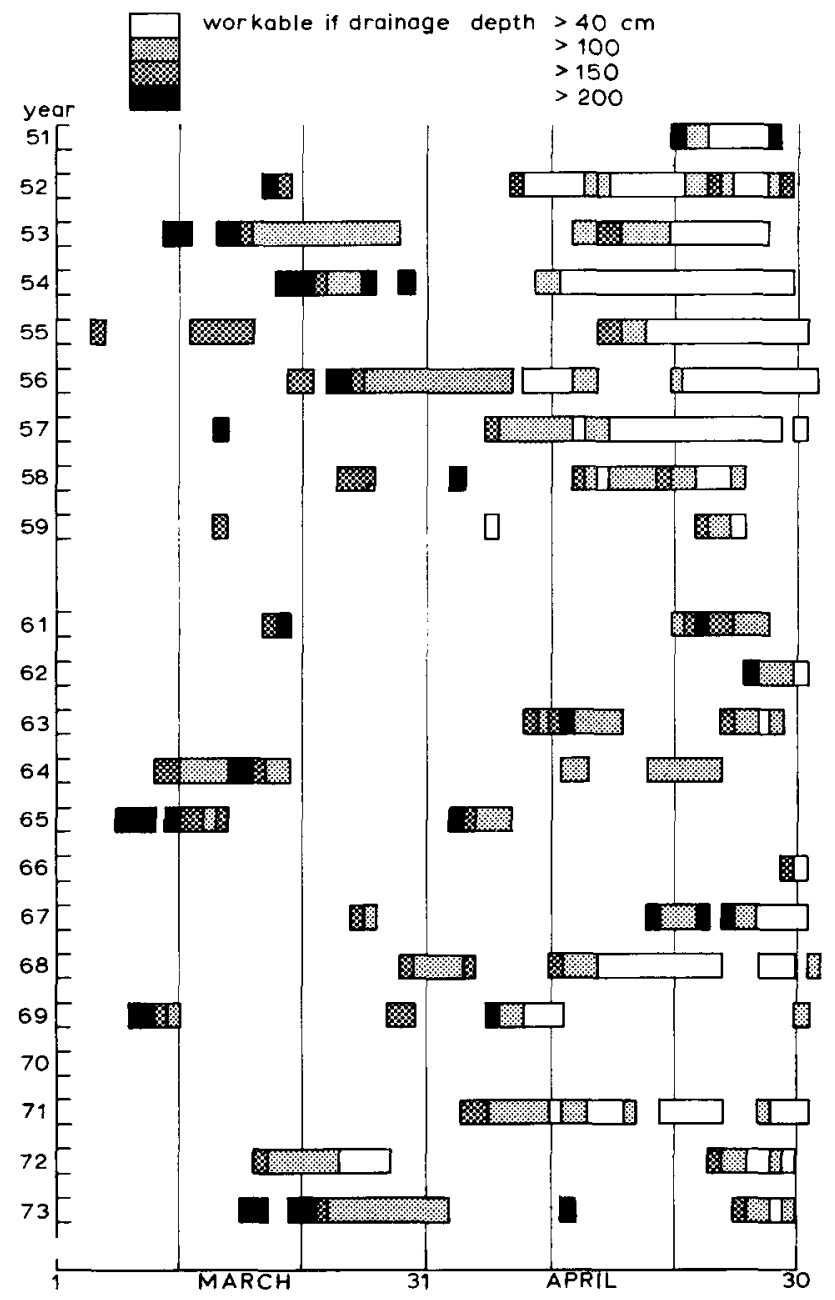

Fig. 10. Periods of workability for 4 drain depths in 22 years. Workability defined as: suction in the top $5 \mathrm{~cm}$ of the profile $\leqslant-300 \mathrm{~cm}$.

time scheme, but earlier workability and thus earlier planting in spring. As Reve \& Fausey (1974) stated, this is perhaps the greatest benefit of drainage.

Fig. 10 gives the periods of workability in 22 years for 4 drainage depths. For all depths the same drainage intensity, 0.015 day $^{-1}$, was used. The year 1960 was omitted because of its unreliable initial condition. The year 1970 gave no workable days in March and April; 1959, 1962 and 1966 had only a few workable days. The experiment did not include the month of May, which afterwards proved to be a mistake.

In a few years (see for example 1951) there is only a small difference in the date 
Table 4. Yield reduction on a sandy loam soil in the Netherlands in $\%$ of maximum yield, as caused by too late planting (mean over the years 1951 through 1973) and drought damage in a model spring of these 22 years, both as dependent on drainage depth (van Wijk \& Feddes, 1975).

\begin{tabular}{|c|c|c|c|c|c|c|}
\hline \multirow{2}{*}{$\begin{array}{l}\text { Drainage } \\
\text { depth } \\
\text { (cm) }\end{array}$} & \multicolumn{2}{|c|}{ Planting date } & \multicolumn{2}{|c|}{ Drought damage } & \multicolumn{2}{|c|}{ Total reduction } \\
\hline & $\begin{array}{l}\text { summer } \\
\text { grains }\end{array}$ & $\begin{array}{l}\text { potato and } \\
\text { sugarbeet }\end{array}$ & $\begin{array}{l}\text { summer } \\
\text { grains }\end{array}$ & $\begin{array}{l}\text { potato and } \\
\text { sugarbeet }\end{array}$ & $\begin{array}{l}\text { summer } \\
\text { grains }\end{array}$ & $\begin{array}{l}\text { potato and } \\
\text { sugarbeet }\end{array}$ \\
\hline 40 & 36.3 & 11.7 & 0.5 & 2.1 & 36.7 & 13.5 \\
\hline 80 & 17.8 & 6.4 & 1.1 & 3.8 & 18.7 & 9.0 \\
\hline 100 & 11.0 & 5.4 & 1.8 & 3.6 & 12.6 & 8.8 \\
\hline 150 & 8.0 & 3.8 & 7.5 & 7.2 & 14.9 & 10.8 \\
\hline
\end{tabular}

of first workability between the 4 drainage depths. In principal the differences are due to differences in drainage depth, but in most years they are amplified by rain storms. Therefore planting dates on shallowly drained soils are usually much later than on deeply drained soils. The effect of planting date on yield has often been studied by agronomists. Wind (1960) calculated from literature data the losses caused by later planting. On basis of that paper and the results of the experiment described in the present paper, van Wijk \& Feddes (1975) calculated the significance of the benefit to be obtained by drainage. They combined the effect of planting date and that of drought damage. Their results are given in Table 4. This table shows that a drainage depth in the investigated sandy loam soil should preferably be between 100 and $150 \mathrm{~cm}$, and it confirms that the common practice of a drainage depth of about $100 \mathrm{~cm}$ is correct. Shallower drainage is certainly not advisable for this soil.

\section{Discussion}

The most remarkable result of the investigation presented here is the conclusion that drainage depth has a considerable and drainage intensity only a small effect on workability in spring. The effect of drainage depth can easily be explained. Deep drainage causes a drier top soil at the end of a wet period than shallow drainage, so less moisture has to evaporate. Moreover the conductivity in dry soil is low, so that the rate of capillary rise in deeply drained soils is lower than in shallowly drained soils. The time required to obtain workability is therefore evidently dependent on drain depth. Why drainage intensity has a lesser effect on workability than drainage depth is less evident. The main explanation is that after a few dry days the effect of drain intensity on depth of watertable is slight compared with the effect of drainage depth. A workable period in spring occurs mostly in a dry period following a rainy one. The depth of watertable at the beginning of the dry period is important for the time required to obtain workability. 
Table 5. Depth of the groundwater table (cm below surface) after a 6-day period of $0.6 \mathrm{~cm}$ rain per day for three drainage depths (D) and three intensities (A).

\begin{tabular}{rlrc}
\hline D $(\mathrm{cm})$ & A $\left(\right.$ day $\left.^{-1}\right)$ & & \\
\cline { 2 - 4 } & 0.005 & 0.010 & 0.015 \\
80 & & 38 & 46 \\
100 & 25 & 58 & 66 \\
150 & 95 & 108 & 116 \\
\hline
\end{tabular}

Groundwater depth can be calculated with the Hellinga-de Zeeuw formula (1958) using a constant moisture storage coefficient:

$$
\mathrm{h}_{\mathrm{t}}=\frac{\mathrm{i}}{\mathrm{A}}\left(1-\mathrm{e}^{-\frac{\mathrm{A}}{\mu} t}\right)+\mathrm{h}_{\mathrm{o}} \mathrm{e}^{-\frac{\mathrm{A}}{\mu} t}
$$

where $\mathrm{h}$ is the height of the watertable above drainage depth $(\mathrm{cm}), \mathrm{i}$ is the rainfall rate $\left(\mathrm{cm}^{\cdot}\right.$ day $\left.^{-1}\right), A$ the drainage intensity $\left(\right.$ day $\left.^{-1}\right), \mu$ the moisture storage coefficient. Calculating the depth of the groundwater after a 6-day period with $0.6 \mathrm{~cm}$ rain per day, following an initial steady state vertical flow of $0.1 \mathrm{~cm}^{\cdot} \mathrm{day}^{-1}$ at three drain depths and three drain intensities, both ranging from poor to very good, and a storage coefficient of 0.05 , will give the results in Table 5 .

The differences in groundwater depths thus calculated at the same drainage intensity equal, of course, the differences in drainage depth. The difference in groundwater depth for intensities of 0.005 and 0.015 day $^{-1}$ was $21 \mathrm{~cm}$, which is small when compared with the $70 \mathrm{~cm}$ groundwater depth difference between the drainage depths 80 and $150 \mathrm{~cm}$.

In most cases the difference in depth of the watertable due to different drainage intensities will be smaller than in the example chosen, since a rainfall of $3.6 \mathrm{~cm}$ in 6 days, as taken in the example, has a probability of about 0.2 in March and April. For a 0.5 probability the rate or the duration is smaller and so the magnitude of the differences also will be smaller.

There are other aspects which favour the effect of drainage depth more than of drainage intensity, e.g. the moisture storage coefficient and the drain discharge during a dry period. All these causes taken together can explain why drainage depth has more influence on workability than drain intensity. To calculate those effects quantitatively, however, a model is required.

An important consequence of the results of the research described is that a low intensity but deep drainage will have a favourable effect on workability. This phenomenon can be observed on many sites where low lying fields, although with an appropriate tile drainage, are later in a workable stage than higher lying fields.

\section{References}

Anonymous, 1971. Beschrijving en analysegegevens van 15 standaardprofielen. Rep. Stiboka 985 , Wageningen. 
Keulen, H. van \& C. G. E. M. van Beek, 1971. Water movement in layered soils - A simulation model. Neth. J. agric. Sci. 19: 138-151.

Perdok, U. D., J. J. Klooster \& M. C. Sprong, 1972. Bewerkbaarheidsonderzoek op akkerbouwbedrijven. Internal Rep. IMAG, Wageningen.

Perdok, U. D., J. J. Klooster \& M. C. Sprong, 1974. De bewerkbaarheid van de grond tijdens de voorjaarswerkzaamheden. Internal Rep. IMAG, No 249, Wageningen.

Perdok, U. D. \& T. Tanis, 1975. Onderzoek naar het aantal werkbare dagen voor de voorjaarsgrondbewerking. Bedrijfsontwikkeling 6: 633-635.

Rijtema, P. E., 1969. Soil moisture forecasting. ICW-note 513, Wageningen.

Wesseling, J., 1969. Bergingsfactor en drainagecriterium. ICW Meded. 118, Wageningen.

Wind, G. P., 1960. Opbrengstderving door te laat zaaien. Landbouwk. Tijdschr. 72: 111-118.

Wind, G. P., 1972. A hydraulic model for the simulation of non-hysteretic vertical unsaturated flow of moisture in soils. $J$. Hydrol. 15: 227-246.

Wind, G. P. \& W. van Doorne, 1975. A numerical model for the simulation of unsaturated vertical flow of moisture in soils. J. Hydrol. 24: 1-20.

Wijk, A. L. M. van \& R. A. Feddes, 1975. Invloed van de waterhuishouding op de opbrengst van landbouwgewassen. ICW-note 867, Wageningen.

Zeeuw, J. W. de \& F. Hellinga, 1958. Neerslag en afvoer. Landbouwk. Tijdschr. 70: 405-421. 